\title{
Brain activity monitoring by compressed spectral array during deep hypothermic circulatory arrest in acute aortic dissection surgery
}

\author{
Tomasz K. Urbanowicz, Wiktor Budniak, Piotr Buczkowski, Bartłomiej Perek, Maciej Walczak, \\ Jadwiga Tomczyk, Sławomir Katarzyński, Marek Jemielity
}

Department of Cardiac Surgery and Transplantology, Chair of Cardiothoracic Surgery, Poznan University of Medical Sciences, Hospital of Lord's Transfiguration, Poznań, Poland

Kardiochirurgia i Torakochirurgia Polska 2014; 11 (4): 409-413

\begin{abstract}
Introduction: Monitoring the central nervous system during aortic dissection repair may improve the understanding of the intraoperative changes related to its bioactivity.

Aim: The aim of the study was to evaluate the influence of deep hypothermia on intraoperative brain bioactivity measured by the compressed spectral array (CSA) method and to assess the influence of the operations on postoperative cognitive function.

Material and methods: The study enrolled 40 patients (31 men and 9 women) at the mean age of $60.2 \pm 8.6$ years, diagnosed with acute aortic dissection. They underwent emergency operations in deep hypothermic circulatory arrest (DHCA). During the operations, brain bioactivity was monitored with the compressed spectral array method.

Results: There were no intraoperative deaths. Electrocerebral silence during DHCA was observed in 31 patients (74\%). The lowest activity was observed during DHCA: it was $0.01 \pm 0.05 \mathrm{nW}$ in the left hemisphere and $0.01 \pm 0.03 \mathrm{nW}$ in the right hemisphere. The postoperative results of neurological tests deteriorated statistically significantly $(26.9 \pm 1.7$ points vs. $22.0 \pm 1.7$ points; $p<0.001$ ), especially among patients who exhibited brain activity during DHCA.

Conclusions: The compressed spectral array method is clinically useful in monitoring brain bioactivity during emergency operations of acute aortic dissections. Electrocerebral silence occurs in $75 \%$ of patients during DHCA. The cognitive function of patients deteriorates significantly after operations with DHCA.

Key words: dissection, DHCA, CSA, brain bioactivity.
\end{abstract}

\section{Streszczenie}

Wstęp: Monitorowanie czynności mózgu podczas operacji rozwarstwień aorty może przyczynić się do lepszego zrozumienia śódoperacyjnych zmian jego czynności bioelektrycznej.

Cel: Ocena śródoperacyjna czynności bioelektrycznej mózgu za pomoca badania skompresowanego rozkładu widma (compressed spectral array - CSA) podczas operacji z zastosowaniem głębokiej hipotermii i czasowego zatrzymania krążenia (deep hypothermic circulatory arrest - DHCA) oraz określenie wpływu operacji na funkcje poznawcze osób operowanych. Materiat i metody: Badaniem objęto 40 chorych (31 mężczyzn i 9 kobiet) w średnim wieku $60,2 \pm 8,6$ roku, z rozpoznaniem ostrego rozwarstwienia aorty, poddanych leczeniu chirurgicznemu w trybie nagłym, z zastosowaniem DHCA. Śródoperacyjnie czynność bioelektryczną mózgu monitorowano za pomocą badania CSA

Wyniki: W okresie śródoperacyjnym nie zmarł żaden pacjent. U 31 chorych (74\%) podczas DHCA obserwowano ciszę bioelektryczną mózgu. Najniższą moc całkowitą aktywności bioelektrycznej mózgu stwierdzono podczas DHCA, odpowiednio, dla półkuli lewej $0,01 \pm 0,05 \mathrm{nW}$ oraz dla półkuli prawej $0,01 \pm 0,03 \mathrm{nW}$. Wyniki testów neurologicznych uległy istotnie statystycznie pogorszeniu przede wszystkim u chorych, u których w okresie DHCA obserwowano aktywność bioelektryczną mózgu.

Wnioski: Podczas operacji w głębokiej hipotermii do całkowitego zaniknięcia czynności bioelektrycznej mózgu dochodzi u ok. $75 \%$ chorych. Funkcje poznawcze u chorych operowanych w głębokiej hipotermii ulegają istotnemu pogorszeniu we wczesnym okresie pooperacyjnym szczególnie u chorych, $u$ których podczas DHCA obserwowano aktywność bioelektryczną mózgu.

Słowa kluczowe: rozwarstwienie, DHCA, CSA, czynność mózgu.

Address for correspondence: Tomasz K. Urbanowicz, Department of Cardiac Surgery and Transplantology, Chair of Cardiothoracic Surgery, Poznan University of Medical Sciences, Hospital of Lord's Transfiguration, 1/2 Długa St., 61-848 Poznań, Poland, phone: +48 618549233 , e-mail: tomasz.urbanowicz@skpp.edu.pl 


\section{Introduction}

The surgical treatment of acute dissections remains a challenge for cardiac surgeons due to the risk of perioperative complications. Monitoring brain function during the procedure is aimed at reducing the risk of central nervous system (CNS) complications. The methods of evaluating the degree of brain injury focusing on biochemical markers (NSE and S100 $\beta$ ) did not find widespread clinical application due to their low specificity [1].

During a surgical procedure, CNS function may be assessed by evaluating: bioelectrical brain activity (electroencephalography, compressed spectral array, bispectral index, somatosensory evoked potentials), blood oxygen saturation in brain tissue (using low infrared light) or blood flow through the cerebral arteries (Doppler ultrasound).

One of the methods of monitoring the brain consists in evaluating its bioelectrical activity with compressed spectral array (CSA). This enables the assessment of the electrical function of each cerebral hemisphere within a given time period. Particularly, the method has been used in intensive care units; many centers consider it as routine examination in this setting [2-4].

The aim of this study was to determine the influence of deep hypothermia during the surgical repair of acute aortic aneurysms involving the ascending aorta and the aortic arch on the bioelectrical activity of the brain using CSA, as well as to determine the impact of said procedures on the cognitive function of patients.

\section{Material and methods}

The study encompassed 40 patients who underwent surgery after being diagnosed with acute aortic dissection. Each diagnosis was confirmed with contrast-enhanced computed tomography. The study group consisted of $40 \mathrm{pa}-$ tients (31 men and 9 women) at the mean age of $60.2 \pm 8.6$ who underwent emergency surgery. The medical history of 29 patients (72\%) included arterial hypertension; bicuspid aortic valve was diagnosed in 9 patients (22.56\%), and 1 patient (2.5\%) was diagnosed with peripheral vascular atherosclerosis. The mean EuroSCORE was $20.8 \pm 9 \%$.

Surgical access was obtained via median sternotomy. The arterial cannula for extracorporeal circulation was introduced into the left femoral artery (39 cases, 97.5\%) or the left subclavian artery (1 case, $2.5 \%$ ). Venous cannulation was performed on the right atrium. After the period of deep hypothermia, a cannula was inserted through a previously introduced prosthesis into the ascending part of the aorta, and extracorporeal circulation was continued through this route.

Body temperature was reduced to $17^{\circ} \mathrm{C}$ (monitored with nasopharyngeal measurements).

Compressed spectral array (CSA) examinations were conducted using an IntelliVue MP70 monitoring system (Koninklijke Philips Electronics N.V., Netherlands). Electrical brain function was monitored with an electroencephalography (EEG) module, M1027A, analyzing two channels of EEG curves (one for each hemisphere) presented in real time. Electroencephalography trends are presented in the form of compressed spectral arrays (CSA) using numerical readings of 3 parameters. The evaluated parameter was total power (TP); the numerical reading of TP indicated the value of power within the whole frequency band (from 0.5 to $30 \mathrm{~Hz}$ ). Total power was recorded in $\mathrm{nW}$. The five electrodes for the CSA examination were placed in a standard fashion (type A), using the international 10-20 system employed routinely in EEG examinations.

\section{Statistical analysis}

Statistical calculations were performed using Statistica 5.5 software (StatSoft, Tulsa, USA). All continuous variables were presented as mean \pm standard deviation (SD). Normal distribution was verified with the Shapiro-Wilk $W$-test. To compare mean values in two groups with normal distribution, data analysis was performed using Student's $t$-test for bound and free variables, respectively. In order to compare mean values in two groups that did not meet normal distribution criteria, the Mann-Whitney U-test was used for free variables, and the Wilcoxon test was employed for bound variables. Qualitative variables were compared using Yates' $\chi^{2}$ test or Fisher's exact test. Linear dependence between two variables that did not follow normal distribution was calculated with Spearman's non-parametric correlation coefficient. The value of $p<0.05$ was considered significant for all statistical tests.

\section{Results}

\section{Intraoperative period}

None of the patients died during the intraoperative period. The procedure consisted in the introduction of a vascular prosthesis into the ascending aorta and the proximal segment of the aortic arch (hemiarch) in 28 patients (70\%), a Bentall procedure in 9 patients (22.5\%), and the introduction of an aortic valve prosthesis with the introduction of a vascular prosthesis of the ascending aorta in 3 patients (7.5\%). Two patients (5\%) underwent repeat surgery due to excessive postoperative drainage. Another two patients (5\%) died on the $3^{\text {rd }}$ and $7^{\text {th }}$ postoperative day due to multiple organ dysfunction syndrome. Total ICU stay was 64.6 $\pm 32.2 \mathrm{~h}$, while mechanical ventilation lasted $18.8 \pm 3.4 \mathrm{~h}$. The mean time of hospitalization was $19 \pm 5$ days. Signs of postoperative psychosis were noted in 19 patients (47\%); they received prolonged sedation with continuous propofol infusion, which resulted in relieving the psychosis.

\section{Compressed spectral array examination}

During the initial examination, no significant difference was noted with regard to the total power (TP) of bioelectrical brain activity between the hemispheres (0.35 $\pm 0.25 \mathrm{nW}$ vs. $0.27 \pm 0.16 \mathrm{nW} ; p=\mathrm{NS}$ ). Throughout the procedure, significant TP reduction was noted in both hemispheres. The lowest activity was observed during deep hypothermic circulatory arrest (DHCA): $0.01 \pm 0.05 \mathrm{nW}$ (left hemisphere) and $0.01 \pm 0.03 \mathrm{nW}$ (right hemisphere). 
After extracorporeal circulation was started, electrocerebral silence (ECS) was noted in 3 patients $(7.5 \%)$ at the temperature of $30.4^{\circ} \mathrm{C}$. In 31 patients (77.4\%), ECS was noted during DHCA. During reperfusion, ECS persisted in 11 patients $(27.5 \%)$ at the temperature of $25.2^{\circ} \mathrm{C}$ and in 2 patients (5\%) it persisted after the end of extracorporeal circulation at the temperature of $36.4^{\circ} \mathrm{C}$. Throughout the observation period, no significant differences were noted between the TP of the two hemispheres. Detailed data concerning the total power of bioelectrical brain activity in group 1 are presented in Figure 1.

The postoperative results of the mini-mental state examination (MMSE) indicated a significant deterioration of all studied parameters. The average postoperative total result was statistically significantly worse $(p<0.001)$, placing the patients in the range of mild dementia. It should be underscored that 7 patients (17.5\%) received a postoperative score of 20 points, corresponding to moderate dementia. The patients who exhibited bioelectrical brain activity during DHCA achieved worse MMSE results (total mean value 21.3; $p<0.05$ ). Four patients from this subgroup (57\%) were postoperatively diagnosed with moderate dementia. The results of MMSE are presented in Table I.

\section{Discussion}

Patients diagnosed with acute aortic dissection who require surgical treatment are characterized by a high risk of intraoperative neurological complications due to the length of the procedure and the primary disorder. Attempts to identify the risk factors for CNS injury and intraoperative monitoring of CNS function facilitate the reduction or elimination of the risk of stroke.

One of the most important problems during surgical procedures using extracorporeal circulation is proper CNS protection. The precise mechanism of brain protection through the use of hypothermia is not fully elucidated [5]. It is assumed that the mechanism is secondary to the reduction in cellular metabolism, although this correlation is not linear in character [6].

Compressed spectral arrays (CSA) of the brain's bioelectrical activity facilitate continuous brain function monitoring on a time axis. The examination has found clinical application in the intraoperative assessment of bioelectrical brain activity in patients undergoing carotid artery endarterectomy [7]. There are few reports concerning the use of

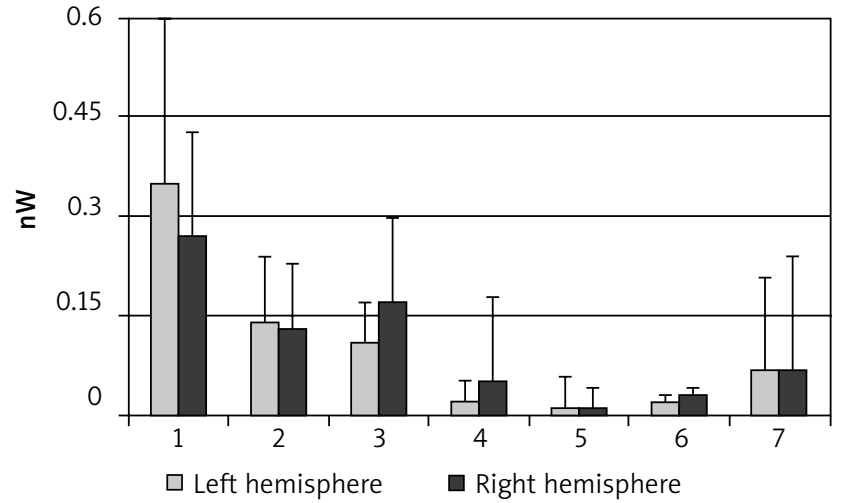

Fig. 1. Total brain bioactivity in each hemisphere measured by compressed spectral array (CSA)

the CSA examination during cardiac surgery. In a study by Sebel, compressed spectral arrays were described as one of the viable and useful examinations during heart operations [8]. The use of CSA for monitoring bioelectrical brain activity during cardiac procedures in order to reduce the risk of neurological complications was also described by Novitzky [9]. The CSA examination was also employed by Ohto et al. in several patients to monitor their brain function during procedures employing extracorporeal circulation, deep hypothermia, and retrograde cerebral perfusion [10].

During extracorporeal circulation, as the patient is cooled, the baseline level of the patient's cellular metabolism is reduced. One manifestation of the metabolic changes occurring within the cells of the central nervous system is the decrease of their bioelectrical activity. This has been confirmed by the performed measurements, in which similar drops in total bioelectrical activity were observed in both hemispheres: from $0.35 \pm 0.25 \mathrm{nW}$ to $0.02 \pm 0.03 \mathrm{nW}$ in the left hemisphere and from $0.27 \pm 0.16 \mathrm{nW}$ to 0.05 $\pm 0.13 \mathrm{nW}$ in the right hemisphere.

During procedures performed under hypothermia, the patient may enter a state of electrocerebral silence (ECS). Our study has confirmed that the temperature at which ECS is achieved varies from individual to individual. In the study group, ECS of both hemispheres was achieved during deep hypothermic circulatory arrest in 31 patients (75.4\%). The conducted examinations showed no return of the brain's bioelectrical activity during reperfusion in some patients. During extracorporeal circulation, no significant differences in activity were observed between the hemi-

Tab. I. Comparison of preoperative and postoperative results of the mini-mental state examination

\begin{tabular}{lccc} 
Parameter & Average preoperative score & Average postoperative score & $p$ \\
Total score & $26.9 \pm 1.7$ & $22.0 \pm 1.7$ & $<0.001$ \\
\hline Orientation to time & $4.3 \pm 0.5$ & $3.1 \pm 0.6$ & NS \\
\hline Orientation to place & $4.6 \pm 0.5$ & $3.1 \pm 0.5$ & $<0.001$ \\
\hline Memory & $2.9 \pm 0.8$ & $2.4 \pm 0.9$ & $<0.05$ \\
\hline Attention & $4.0 \pm 0.9$ & $3.1 \pm 0.7$ & $<0.05$ \\
\hline Recall & $2.9 \pm 0.7$ & $2.1 \pm 0.5$ & $<0.01$ \\
\hline
\end{tabular}


spheres, which may indicate comparable cerebral flow in both hemispheres despite the presence of dissection.

The obtained results confirm that hypothermia sensitivity is individually variable with general features of response to moderate hypothermia characterized by a reduction in bioelectrical brain activity. The results indicate the need for examining bioelectrical brain activity in order to determine the individual DHCA parameters for each patient.

ECS at the temperature of $17^{\circ} \mathrm{C}$ was achieved in approximately $77 \%$ of the patients. According to other authors, a complete lack of brain waves at the temperature of approximately 17 degrees can be observed in approximately $50 \%$ of patients [11]. In turn, at the temperature of $18^{\circ} \mathrm{C}$, electrical function can be observed in $40 \%$ of cases [12].

In the case of procedures performed under deep hypothermia, applying ice packs locally in accordance with recommendations (around the head, including the occipital area) facilitates the preservation of low CNS temperature.

It appears that the preservation of CNS function may be influenced by other factors besides temperature, which can slow down or accelerate metabolism. For example, injuries sustained as a result of the reperfusion mechanism may lead to reversible or even irreversible changes in organs including the CNS. Within the brain, an additional damaging stimulus during reperfusion is constituted by neural hyperreactivity inducing excessive release of toxic neurotransmitters. The brains of mammals are especially sensitive to their own neurotransmitters being released into the intercellular space [13]. When released from damaged cells, glutamate, the most important of excitatory neurotransmitters, exerts a toxic effect on its environment by exciting the receptors of some cells [14-16].

During extracorporeal circulation, hematocrit values were maintained within the range of $20-30 \%$ in accordance with the assumptions concerning the compensatory influence of hemoglobin on hypothermia and the protective function of hemodilution. It has been demonstrated that, in the case of $30 \%$ and $20 \%$ values of hematocrit, the need for oxygen may be compensated; in such concentrations, intracellular acidosis is not present or remains minimal, depending on the level of hemodilution [17].

Apart from the attempt to evaluate the usefulness of CSA in the cardiac operating room, an attempt was made to assess the influence of aortic aneurysm and dissection repair on the preservation of cognitive function. Although the bioelectrical activity of the patients' brains returned to baseline values, limitations of cognitive function were observed. The deterioration was especially apparent in the group of patients operated on under deep hypothermia. The impairments in this group of patients involved memory range, orientation to location, as well as the ability to focus and recall memories. Short- and long-term memory impairments as well as longer time required for performing neuropsychological tests may be related to impaired carbohydrate metabolism during extracorporeal circulation [18]. An increased number of errors in neuropsychological tests and longer performance time were noted in patients with hyperglycemia in type 1 and 2 diabetes [19].

\section{Study limitations}

The CSA examination does not provide information concerning the possible impairments in specific regions of the brain. It only analyzes the total activity in a given hemisphere, which constitutes a significant limitation of the method. In turn, the analysis of bioelectrical activity is only a method of computer analysis.

\section{Conclusions}

Based on the performed CSA examinations, it has been concluded that, during procedures conducted under moderate hypothermia, the total power of bioelectrical brain function is reduced over five-fold. During operations conducted under deep hypothermia, electrocerebral silence occurs in approximately $77 \%$ of patients.

Based on the performed MMSE, it has been demonstrated that the cognitive function of patients operated on under deep hypothermia deteriorates significantly during the early postoperative period, especially among patients in whom bioelectrical brain activity was observed during DHCA.

\section{Disclosure}

Authors report no conflict of interest.

\section{References}

1. Maragos PJ, Schmechel DE. Neuron specific enolase, a clinical useful marker for neurons and neuroendocrine cells. Annu Rev Neurosci 1987; 10: 269-295.

2. Takeichi T, Asonuma K, Kim I. Compresed spectral arrays of patients with fulminant hepatic failure In hepatic coma undergoing liver transplantation. Clin Transplant 2002; 16: 273-279.

3. Bricolo A, Turazzi S, Faccioli A. Clinical aplication of compresed sectral array in long-term EEG monitoring of comatose patients. Electroenceph Clin Neurophysiol 1978; 45: 211-225.

4. Karnaza DS, Marshall LF, Bickford RG. EEG monitoring of clinical coma: compressed spectral array. Neurology 1982; 32: 289-286.

5. Hoffman WE, Charbel FT, Munoz L, Ausman JI. Comparison of brain tissue metabolic changes during ischema at 35 degrees and 18 degrees $C$. Surg Neurol 1998; 49: 85-89.

6. Michenfelder JD, Milder JH. The relationship among canine brain temperature, metabolism, and function during hypothermia. Anesthesiology 1991; 75: 130-136.

7. Bowdle A, Rooke GA, Kazmers A. Intraoperative stroke during carotid endarterectomy without a change in the spectral edge frequency of the compressed spectral array. J Cardiothorac Anesth 1988; 2: 204-206.

8. Sebel PS. Central nervous system monitoring during open heart surgery: an update. J Cardiothorac Vasc Anesth 1998; 12 (suppl 1): 1-3.

9. Novitzky D. Reducing the risk of myocardial revascularization: relevance of mutlimodal brain monitoring. Semin Cardiothorac Vasc Anesth 2005; 9 : 131-137.

10. Ohto T, Honma K, Takahara Y, Sezaki T, Sudo Y, Murayama H, Nakamura T. Monitoring of electroencephalogram during the operation under the extracorporeal circulation. Nippon Kyobu Geka Gakkai Zasshi 1994; 42: 18851891.

11. Stecker MM, Cheung AT, Pochettino A, Kent GP, Patterson T, Weiss SJ, Bavaria JE. Deep hypothermia circulatory arrest: I. Effects of cooling on electroencehalograms and evoked potentials. Ann Thorac Surg 2001; 71: 14-21.

12. McCullough JN, Zhang H, Reich DL, Juvonen TS, Klein JJ, Spielvogel D, Ergin MA, Griepp RB. Cerebral metabolit suppresion during deep hypothermic circulatory arrest in humans. Ann Thorac Surg 1999; 67: 1895-1899.

13. Lipton SA, Rosenberg PA. Excitatry amino acids as a final pathway for neurologic disorders. N Eng J Med 1994; 330: 613-622. 
14. Samuels A, Seifter S, Lipton SA. Excitatory amino acids in a neurologic disorders. N Engl J Med 1994; 331: 274-275.

15. Siesjö BK, Zhao Q, Pahlmark K, Siesjö P, Katsura K, Folbergrová J. Glutamate, calcium, and free radicals as mediators of ischemic brain damage. Ann Thorac Surg 1995; 59: 1316-1320.

16. Nakashima K, Todd MM. Effects of hypothermia on the rate of the excitatory amino acid release after ischemic depolarization. Stroke 1996; 27: 913-918.

17. Shin'oka T, Shum-Tim D, Jonas RA, Lidov HG, Laussen PC, Miura T, du Plessis A. Higher hematocrit improves cerebral outcome after deep hypothermic circulatory arrest. J Thorac Cardiovasc Surg 1996; 112: 1610-1621.
18. Michalak S, Kozubski W. Upośledzenie funkcji poznawczych u chorych z zaburzeniami przemiany węglowodanów. Medycyna po Dyplomie 2007; 7: 61-70.

19. Cox DJ, Kovatchev BP, Gonder-Frederick LA, Summers KH, McCall A, Grimm KJ, Clarke WL. Relationships between hyperglycemia and cognitive performance among adults with type 1 and type 2 diabetes. Diabetes Care 2005; 28: 71-77. 